\section{Potential Roles of the Neural Stem Cell in the Restoration of the Injured Spinal Cord: Review of the Literature}

\section{Omurilik Yaralanmasının Tedavisinde Nöral Kök Hücrenin Potansiyel Rolleri: Literatürün Gözden Geçirilmesi}

\begin{abstract}
The use of stem cells in the treatment of traumatic spinal cord injury (SCI) in recent years has provided promising results. Different sources of cells for transplantation have been used, including neural progenitor cells (NPCs), neural stem cells (NSCs) or embryonic stem cells (ESCs). Experimental and clinical studies are currently underway to define the potentials of stem cells in the treatment of SCI. As implantation-based neural cellular restoratory therapy develops, SCI that has not been typically treated by surgical procedures, will be ultimately introduced within the realm of neurosurgery. It is thus imperative that neurosurgeons have an understanding of and in-depth training in research endeavors related to the field of stem cell biology. This paper aims to briefly review the current status and potential of using stem cells to repair experimental SCI.

KEYWORDS: Embryonic stem cells, Neural stem cells, Neurosurgery, Spinal cord injury, Treatment, Stem cell

\section{Öz}

Son yıllarda, travmatik omurilik yaralanmasının (OY) tedavisinde kök hücrelerin kullanımının umut vaad eden sonuçları vardır. Nöral progenitor hücreler (NPH), nöral kök hücreler (NKH) veya embriyonik kök hücreler (EKH) gibi transplantasyon için kullanılabilecek değişik kaynak kök hücreler mevcuttur. OY tedavisinde kök hücrelerin potansiyel olarak kullanımı için deneysel ve klinik çalışmalar halen devam etmektedir. İmplantasyon yapılarak sinir hücrelerinin tedavi olanağı geliştikçe, genellikle cerrahi girişim ile tedavi edilmeyen OY nöroşirürji alanına girecektir. Bu nedenle, kök hücre biyolojisi alanında nöroşirürjiyenlerin eğitimi gereklidir. Bu yazıda, kısaca kök hücre araştırmalarındaki mevcut durum ve deneysel OY tedavisinde kök hücre kullanımının yeri özetlenmiştir.
\end{abstract}

ANAHTAR SÖZCÜKLER: Embriyonik kök hücreler, Nöral kök hücreler, Nöroşirürji, Omurilik yaralanması, Tedavi, Kök hücre

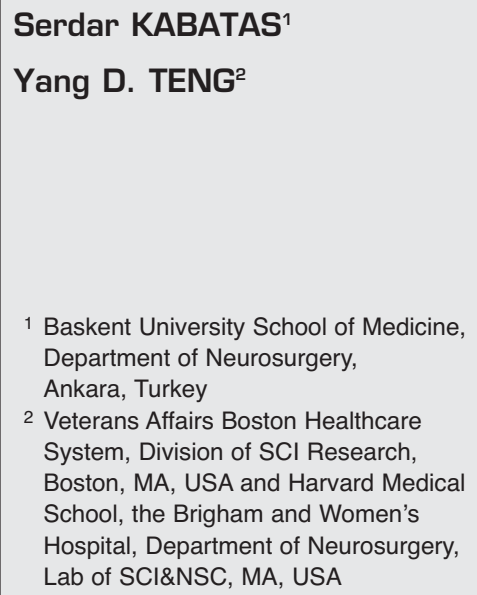

2 Veterans Affairs Boston Healthcare System, Division of SCI Research, Boston, MA, USA and Harvard Medical School, the Brigham and Women's Hospital, Department of Neurosurgery, Lab of SCI\&NSC, MA, USA

Received : 17.02.2010

Accepted : 22.02.2010

Correspondence address:

Serdar KABATAS

E-mail: kabatasserdar@hotmail.com 


\section{INTRODUCTION}

Traumatic spinal cord injury (SCI) often results in significant neurologic dysfunction and disability. The annual incidence of SCI in developed countries varies from 11.5 to 53.4 per million population (23, 46). Much research over the past 30 to 40 years has focused on elucidating the mechanisms underlying the complex pathophysiologic processes being slowly unraveled following SCI. It is now generally accepted that acute SCI is a two-step processes involving primary and secondary events $(3,14,51)$. The primary process involves the initial mechanical injury due to local deformation and energy transformation, whereas the secondary mechanism encompasses a cascade of biochemical and cellular processes that are initiated by the primary process and may cause ongoing cellular damage, cell death, axonal loss and demyelination (3, 46, 51). These pathophysiological features plus the dearth of available treatment options for SCI have made the injured spinal cord an attractive target for studying cell-based therapies $(5,16,33,41)$. Importantly, it has been increasingly appreciated that with effective neuroprotection in place provided by donor cells including neural stem cells (NSCs), other treatments aiming to promote axonal regrowth and neural plasticity, if started simultaneously or immediately thereafter, may synergistically enhance functional restoration (5). In pursuing this possibility, experimental use of neurotrophins or neurotrophic factors to increase neuroprotection and axonal growth, neutralizing antibodies to Nogo and other oligodendrocyte-related inhibitory molecules and drugs to increase intracellular levels of cAMP have been investigated $(2,4,5,35,45,56)$. Furthermore, several studies have suggested that NSCs, when transplanted into the injured brain or spinal cord of rodents, migrate preferentially to and become integrated within the damaged areas. A subpopulation of the transplanted NSC is redirected to differentiate into cell types that might replace the diseased or degenerated host cells $(36,37$, $43,60)$. Thus, the initial primary rationale was that cell-based strategies for reconstituting the injured spinal cord must accommodate the need to replace multiple cell types $(13,16,49)$.

\section{Definition of Stem Cells}

Stem cells are defined as immature, uncommitted cells that are able to self-replicate in tissue culture, and differentiate into most lineages of cells. Embryonic stem cells (ESCs) are derived from the inner cell mass of an embryo in the blastocyst stage and are totipotent, i.e., with the ability to form all cell types and tissues from all embryonic germ layers, including neural tissues $(42,62)$. Multipotent NSCs, which have the ability to differentiate into all neural cell types (i.e., neurons, astrocytes and oligodendrocytes), are derived from the neural tube, subventricular zone and/or germinal matrix of a developing fetus brain and propagated in specific growth factor enhanced media $(15,48)$. These cells have the ability to form neurons, astrocytes, and oligodendrocytes given the appropriate developmental cues or culture conditions. Indeed, when transplanted into the developing nervous system, NSCs disseminate throughout the central nervous system (CNS) and integrate within the developing neural networks. Both ES cells and NSCs have been investigated for their potential role in the treatment of SCI. Stem cells, theoretically, are able to provide an unlimited source of donor cells for transplantation through in vitro expansion in an undifferentiated state. In experimental models, neural stem cells have been shown to have the ability to engraft and integrate into diseased CNS, repopulate specific types of degenerating cells, and express therapeutic foreign genes (15).

\section{Potential for Using NSCs to Repair the Injured Spinal Cord}

SCI is associated with the loss of both neurons and glia $(13,55)$. Improved functional outcomes after SCI may be elicited by neuroprotective approaches that limit secondary tissue loss and thus the loss of function. Alternatively, functional recovery could be elicited by axon growth and neural plasticitypromoting approaches that result in restoration of damaged and/or formation of new neural circuits that could become involved in functional recovery $(22,55)$. There is little doubt that stem cells and neural progenitor cells could become invaluable components of repair strategies for the spinal cord. NSCs, by definition, can become neural cells that may support anatomical/functional recovery. Alternatively, they may secrete growth factors that could support neuroprotection and/or neurite reorganization. The potential of stem cells or progenitor cells to mediate spinal cord repair has been studied extensively $(10,17,55,59)$. The 
potential problems related to stem cell application to neural repair have also been discussed $(9,57,59,63)$. For instance, over the last decade, stem cells have often been studied without implementing explicit bench criteria that would define the used cells as such. These and other matters regarding the use of stem/progenitor cells for SCI treatment also need to be resolved before effective therapies can be developed (63).

\section{Clinical Potential of NSCs}

Various treatment strategies have shown benefit in experimental animal models, there is still no effective therapy for clinical SCI. This difficult situation, in our opinion, is attributable to the following realities. First, there has been no conclusive evidence favoring one process as the predominant pathophysiological mechanism which can account for all the spinal dysfunction seen following SCI. Most of the pathophysiological processes (e.g., secondary molecular events: glutamate toxicity, sodium and calcium influx, free radical insult, cytochrome c release; secondary pathophysiological events: ischemia, anoxia, apoptosis, etc.) apparently exist either simultaneously or sequentially in an interlocked or independent manner throughout the evolution of the injury and represent different facets of this complicated disease entity (3, 51, 52). Most interventions reported to date target solely one facet of the injury process which, in isolation, is doomed to have limited benefit. To further complicate the situation, a given approach that may be useful when used alone, may become ineffective or even detrimental when used in combination with other interventions, perhaps working at cross purposes. Hence, it is critical to understand the intricate interactions between these options and identify the underlying mechanisms of their actions so that they may be orchestrated in a safe, synergetic, and clinically feasible fashion $(5,41)$. Given these challenges, the use of a "therapeutic anchoring vehicle" such as the NSC has been deemed to be an appealing strategy to address multiple pathological processes simultaneously while effecting functional recovery $(55,56,57)$. In an ideal situation, the "therapeutic anchoring agent" should be (a) multipotent in terms of assuming the roles of different neural cell lineages and performing different functions, including functions at play early in development such as the regulated release of neurotrophic factors and other homeostasismaintaining agents, and (b) capable of modifying the restrictive environment of the post-injury CNS, while not being vulnerable to most of the secondary injury molecules. NSCs, given their innate biology (and when presenting with appropriate doses and functional dynamics), appear to be favorable candidates for the role of therapeutic anchor vehicle in treatment of traumatic CNS lesions. This notion has been supported by outcomes from laboratory studies. For example, animal studies have, in most cases, consistently shown that neurologic recovery is enhanced by stem cell implantation after injury, and the most widely employed method of NSC delivery utilizes cell transplantation technology. To better direct neural repair following SCI, we previously proposed an implant that mimics the general structure of the healthy spinal cord (54). The construct consisted of an inner section, engineered to emulate gray matter, with an isotropic pore structure of $250-500 \mu \mathrm{m}$ in diameter to facilitate the seeding of the NSC's, and an outer section modeled to emulate white matter with long, axially oriented pores for axonal guidance and radial porosity to allow fluid transport while inhibiting the ingrowth of scar tissue. Implantation of the scaffold-neural stem cells (i.e., a genetically immortalized mouse NSC line) unit into an adult rat hemisection model of SCI promoted long-term improvement in function relative to a control group. At 70 days post-injury, animals implanted with scaffold-plus-cells exhibited coordinated, weight-bearing hindlimb stepping. Histological and immunocytochemical analysis suggested that this recovery was not caused by neural cell replacement but, instead, was attributable predominantly to a reduction in tissue loss from secondary injury processes as well as to diminished glial scarring. This work was the first to explicitly advocate the "by-stander" neuroprotective effects of NSCs. Tract tracing demonstrated corticospinal tract fibers passing through the injury epicenter to the caudal side of the lesion, a phenomenon not present in untreated groups. Together with evidence of enhanced local GAP-43 expression, an axonal growth marker, not seen in controls, these findings suggested a possible neuroplastic/ regenerative component in the therapeutic effects of NSCs which might have further facilitated the functional recovery. Besides suggesting a new paradigm for 
treating SCI, these results may serve more broadly as a prototype for the anchoring by NSCs of multidisciplinary strategies of regenerative medicine (i.e., anti-secondary injury including antiinflammation, mitigation of astrogliosis, tissue engineering, trophic factor delivery, gene therapy, and material sciences) in the setting of complex neurological disorders. More recently, Song et al showed that in the rats that received hNSC transplantion during subacute phase following trauma, showed better survival and differentiation of donor cells (50). They therefore suggested that NSC transplantations should be performed during the subacute stage after injury to achieve maximum therapeutic potential, which additionally indicates that there may be a practical therapeutic window for applying NSC to treat SCI clinically (50).

\section{Comprehensive Impact of NSC on the Injured Spinal Cord}

To date, as a therapeutic tool in the treatment of neurologic disorders, the most promising results have been obtained using hNSC isolated directly from the human fetal neuroectoderm. The propagation ability of such tissue-derived hNSC is sometimes limited, making it difficult to establish a large-scale culture. Following engraftment, these hNSC often show low efficiency in generating the desired neuronal cells necessary for reconstruction of the damaged host milieu and, as a result, have failed to give satisfactory results in clinical trials so far. Alternatively, human embryonic stem cells (hESC) or induced ploripotent stem (iPS) cells offer a pluripotent reservoir for in vitro derivation of a rich spectrum of well-characterized neural-lineage committed stem/progenitor/precursor cells that can, theoretically, be picked at precisely their safest and most efficacious state of plasticity to meet a given clinical challenge (38). Considering the ability of stem cells to become any cell types they are related developmentally, their potential use for cell replacement is a common sense-derived strategy (59), for this purpose, ESCs or iPS cells are indeed likely sources for cell replacement treatment of SCI. On the other hand, one of the main problems of ES or iPS cell-based cell therapy is tumor formation, to date there is no an ideal method to suppress tumor development from ESCs/iPSCs (29). Conversely, with the appropriate combination of (growth) factors (induction cocktail), ESCs can be used to obtain neurons and glial cells (1, 27, 59). Interestingly, Matsuda et al. showed that bone marrow stromal cells (BMSCs) could help induce undifferentiated ESCs to differentiate into a neuronal lineage by neurotrophic factor production, resulting in suppression of tumor formation. They hence recommended that cotransplantation of BMSCs with ES cell-derived graft cells may be useful for preventing the development of ES cell-derived tumors (29). With respect to human ESCs' potential to be directed toward generating multipotent neural precursors, motor neurons, and oligodendrocyte progenitor cells $(8,21,25,26,59)$, the latter were found to be capable to differentiate into mature oligodendrocytes in vitro and in vivo $(34,59)$. Moreover, these cells are able to myelinate axons after transplantation into the spinal cord of myelindeficient shiverer mice and adult rats $(21,59)$.

NSC implants into the injured spinal cord have been used under the initial premise that regionally appropriate phenotypes might be generated from undifferentiated cells in response to local signals competent to induce cell type-specification (16). However, more intriguingly - ultimately, of greater importance and utility - is the observation that undifferentiated NSC or NSC that have pursued a glial lineage seem to recondition the host CNS microenvironment and promote functional recovery by protecting pre-existent but threatened host neurons and circuitry (54). The impact of this action is probably greater than neuronal replacement. The precise mechanism by which NSC exert this homeostatic pressure is unclear, though it is likely attributable to a large degree by intrinsic ability of NSC to secrete neurotrophic factors, and/or immunomodulators, and form gap junctions with host cells $(18,28,39,40,54,56)$. Thus, preserving the multipotency of these cells - as opposed to attempting to direct them invariantly down the differentiation pathway of a single cell type - might offer the greatest chance for cell-based therapies of the different inter-locked stages of SCI but in a parsimonious fashion. Harnessing the potentially broad therapeutic capacity of the NSC for use in an intelligent and rationale manner requires learning the principles that can govern interaction between the pathologic target and host environmental components, the NSC, and other therapeutic reagents. 
The innate biology of NSC (i.e., their default production and secretion of various neurotrophic factors and other molecules in a differentiation stage-dependent fashion) enables them to interact with the surrounding environment, including releasing trophic factors in an appropriate, regulated, stimulusappropriate manner. These factors, in our view, are components of the stem cell's inherent developmental program which "calls upon it" to exert homeostatic forces upon a dynamically growing nervous system which, otherwise, could become dysequilibrated. The result of this inherent "program" - a dividend from developmental biology - is to promote, enable, induce, or catalyze the host to attempt to reconstitute its own tissue, to minimize barriers to this process, and to protect endangered cells from cell death or other toxic influences (53).

Regarding endogenous NSC and their possible roles in SCI repair, these cells have been found to reside in a few well-characterized secondary germinal zones of the adult central nervous system, most notably the subgranular zone (SGZ) of the dentate gyrus of the hippocampus and the subventricular zone (SVZ) along the anterior part of the lateral ventricle in the forebrain. Endogenous NSC may also reside in the ependymal region of the spinal cord. In response to injuries like stroke, adult hippocampal NSC may proliferate and differentiate into new, functioning neurons (44). However, NSC in the adult spinal ependymal region do not seem to differentiate into neurons when they reside in their normal spinal cord niche. Nevertheless, when these same NSC are transplanted into the SGZ, they do yield neurons $(12,19,47)$. Hence, limitations to neurogenesis must emanate in large part from the microenvironment of the adult spinal cord rather than from the cells themselves. Therefore, it seems feasible that either altering the milieu or changing the cells to respond differently to that milieu may permit these endogenous spinal NSC to play a more prominent role in neuronal reconstitution in the adult cord $(11,55)$. To overcome the normal impediments to adult neurogenesis will require a better understanding of the biological roles of spinal NSC, especially their proliferation in response to injury, inflammation, and rehabilitation-mediated neuroactivity - all significantly unexplored (55).

Additionally, murine ESCs were observed to survive and promote recovery in the contused spinal cord (30). Although this recovery was at first attributed to the few neurons that appeared to emerge, a more detailed study showed that functional impact may, in fact, have been more plausibly due to oligodendrocyte that myelinated some traumatized host axons (27). Since the injured cord offers a microenvironment that appears not favorable to the differentiation of multipotent NSC into neurons (7), it has been proposed that transplanting neuronal and glial restricted precursors (NRP/GRP: i.e., pre-committing the cells to a particular lineage ex vivo rather than letting the in vivo environment direct their differentiation) may be a more practical approach.

The transplantation of NRP/ GRP into the postcontusion spinal cord did improve motor and sensory function. Histological analysis showed that a subset of the NRP/GRP survived, filled the lesion site, differentiated into neurons and glia, and migrated selectively $(6,31)$. Interestingly, the volume of spinal cord spared was increased in NRP/ GRP recipients, suggesting that their action may nevertheless have been attributable in a large part to local neuroprotection. The actual role that donorderived neurons played in recreating neurocircuitry is presently not determined. Kumagai and colleagues showed that transplantation of the gliogenic secondary neurospheres (SNS), but not the neurogenic primary neurospheres (PNS), promoted axonal growth, remyelination, and angiogenesis, and resulted in significant locomotor functional recovery after subacute SCI rodent model. Their finding suggests that gliogenic neural stem/progenitor cells (NS/PCs) may be also effective for promoting the recovery from SCI, and may provide an additional tool to investigate the mechanisms through which cellular transplantation leads to functional improvement after SCI $(13,24)$. Thus, further investigation is necessary to precisely define the cell biology, safety, and potential therapeutic benefits of transplanted stem cells that are predifferentiated into neural cells prior to their introduction into formal clinical trials.

\section{Future Directions of Functional Restoration for SCI}

As data elucidating the complexity of spinal cord injury pathophysiology emerge, it is increasingly being recognized that successful repair will probably require a multifaceted approach that combines 
tactics from various biomedical disciplines, including cell transplantation, gene therapy, material sciences and pharmacology. Recently, new evidence highlighting the benefit of physical activity and rehabilitation interventions during the postinjury phase has provided novel possibilities in realizing additional efficacy of NSC-mediated repair after spinal cord injury. However, we believe that the basic mechanisms by which these various interventions act must be thoroughly explored and important synergistic and antagonistic interactions identified, before a comprehensive therapeutic strategy that optimally utilizes the benefits of each of these disciplines can be designed. In examining the mechanisms by which physical activity-based functional recovery after spinal cord injury is affected, endogenous neural stem cells, in our opinion, engender a potentially key role that theoretically can be mimicked or further augmented by transplantation of human NSC or other types of progenitor cells (32). In terms of applying chemical engineering strategies to additionally enhance the therapeutic potential of stem cells, the use of scaffolds and cellular bridges are well-suited for lesions in which there is large parenchymal loss or where a syrinx might otherwise form because of extensive cell death following contusion $(54,61)$. Recently, others and we have shown that the ability of fibrin scaffolds or drug-embedding PLGA to exert the controlled release of growth factors or free radical scavengers to enhance the survival/ differentiation of neural progenitor cells and impede secondary injury, respectively, following transplantation into a SCI model (20).

In summary, the experimental data, overall, advocates the incorporation of stem cell implantation or activation of endogenous NSCs as a component of the multidimensional treatment of spinal cord injury and underscores the critical need to employ research-based mechanistic approaches for developing future advances in the stem cell therapies for neurological injury and disorders.

\section{ABBREVIATIONS}

Bone marrow stromal cells (BMSCs); central nervous system (CNS); cyclic Adenosine Monophosphate (cAMP); embryonic stem cells (ESCs); human embryonic stem cells (hESC); human neural stem cell (hNSC); neuronal and glial restricted precursors (NRP / GRP); neural progenitor cells (NPCs); neural stem/ progenitor cells (NS/PCs); neural stem cells (NSCs); primary neurospheres (PNS); secondary neurospheres (SNS); spinal cord injury (SCI); subgranular zone (SGZ); subventricular zone (SVZ)

\section{ACKNOWLEDGEMENT}

Yang D. Teng, MD, PhD is supported by VA Merit Grants, NIH, CIMIT and the State of Massachussets.

\section{REFERENCES}

1. Billon N, Jolicoeur C, Raff M: Generation and characterization of oligodendrocytes from lineage-selectable embryonic stem cells in vitro. Methods Mol Biol 330: 15-32, 2006

2. Blesch A, Tuszynski MH: Spontaneous and neurotrophininduced axonal plasticity after spinal cord injury. Review. Prog Brain Res 137: 415-423, 2002

3. Bramlett HM, Dietrich WD: Progressive damage after brain and spinal cord injury: Pathomechanisms and treatment strategies. Review. Prog Brain Res 161: 125-141, 2007

4. Bregman BS, Coumans JV, Dai HN, Kuhn PL, Lynskey J, McAtee M, Sandhu F: Transplants and neurotrophic factors increase regeneration and recovery of function after spinal cord injury. Review. Prog Brain Res 137: 257-273, 2002

5. Bunge MB: Novel combination strategies to repair the injured mammalian spinal cord. Review. J Spinal Cord Med 31: 262269, 2008

6. Cao Q, Xu XM, Devries WH, Enzmann GU, Ping P, Tsoulfas P, Wood PM, Bunge MB, Whittemore SR: Functional recovery in traumatic spinal cord injury after transplantation of multineurotrophin-expressing glial-restricted precursor cells. J Neurosci 25: 6947-6957, 2005

7. Cao QL, Howard RM, Dennison JB, Whittemore SR: Differentiation of engrafted neuronal-restricted precursor cells is inhibited in the traumatically injured spinal cord. Exp Neurol 177: 349-359, 2002

8. Carpenter MK, Cui X, Hu ZH, Jackson J, Sherman S, Seiger A, Wahlberg LA: In vitro expansion of a multipotent population of human neural progenitor cells. Exp Neurol 158: 265-278, 1999

9. Chen HI, Bakshi A, Royo NC, Magge SN, Watson DJ: Neural stem cells as biological minipumps: a faster route to cell therapy for the CNS? Review. Curr Stem Cell Res Ther 2: 1322,2007

10. Coutts M, Keirstead HS: Stem cells for the treatment of spinal cord injury. Review. Exp Neurol 209: 368-377, 2008

11. Danilov AI, Covacu R, Moe MC, Langmoen IA, Johansson CB, Olsson T, Brundin L: Neurogenesis in the adult spinal cord in an experimental model of multiple sclerosis. Eur J Neurosci 23: 394-400, 2006

12. Doetsch F, Caille I, Lim DA, Garcia-Verdugo JM, AlvarezBuylla A: Subventricular zone astrocytes are neural stem cells in the adult mammalian brain. Cell 97: 703-716, 1999

13. Enzmann GU, Benton RL, Talbott JF, Cao Q, Whittemore SR: Functional considerations of stem cell transplantation therapy for spinal cord repair. Review. J Neurotrauma 23: 479-495, 2006 
14. Fehlings MG, Sekhon LHS: Cellular, ionic and biomolecular mechanisms of the injury process. Tator $\mathrm{CH}$, Benzel EC (eds), Contemporary Management of Spinal Cord injury: From Impact to Rehabilitation, New York: American Association of Neurological Surgeons, 2000: 33-50

15. Flax JD, Aurora S, Yang C, Simonin C, Wills AM, Billinghurst LL, Jendoubi M, Sidman RL, Wolfe JH, Kim SU, Snyder EY: Engraftable human neural stem cells respond to developmental cues, replace neurons, and express foreign genes. Nat Biotechnol 16: 1033-1039, 1998

16. Goldman SA, Windrem MS: Cell replacement therapy in neurological disease. Philos Trans R Soc Lond B Biol Sci 29: 1463-1475, 2006

17. Hardy SA, Maltman DJ, Przyborski SA: Mesenchymal stem cells as mediators of neural differentiation. Review. Curr Stem Cell Res Ther 3: 43-52, 2008

18. Jäderstad J, Jäderstad LM, Li J, Chintawar S, Salto C, Pandolfo M, Ourednik V, Teng YD, Sidman RL, Arenas E, Snyder EY, Herlenius E: Communication via gap junctions underlies early functional and beneficial interactions between grafted neural stem cells and the host. Proc Natl Acad Sci USA Feb 10: 2010

19. Johansson CB, Momma S, Clarke DL, Risling M, Lendahl U, Frisen J: Identification of a neural stem cell in the adult mammalian central nervous system. Cell 96: 25-34, 1999

20. Johnson PJ, Tatara A, Shiu A, Sakiyama-Elbert SE: Controlled release of neurotrophin-3 and platelet derived growth factor from fibrin scaffolds containing neural progenitor cells enhances survival and differentiation into neurons in a subacute model of SCI. Cell Transplant Oct 9: 2009

21. Keirstead HS, Nistor G, Bernal G, Totoiu M, Cloutier F, Sharp K, Steward O: Human embryonic stem cell-derived oligodendrocyte progenitor cell transplants remyelinate and restore locomotion after spinal cord injury. J Neurosci 25: 4694-4705, 2005

22. Konya D, Liao WL, Choi H, Yu D, Woodard MC, Newton KM, King AM, Pamir NM, Black PM, Frontera WR, Sabharwal S, Teng YD: Functional recovery in T13-L1 hemisected rats resulting from peripheral nerve rerouting: role of central neuroplasticity. Regen Med 3: 309-327, 2008

23. Kraus JF, Silberman TA, McArthur DL: Epidemiology of spinal cord injury. Benzel EC, Cahill DW, McCormack P (eds): Principles of Spine Surgery. New York: McGraw-Hill, 1996: $41-58$

24. Kumagai G, Okada Y, Yamane J, Nagoshi N, Kitamura K, Mukaino M, Tsuji O, Fujiyoshi K, Katoh H, Okada S, Shibata S, Matsuzaki Y, Toh S, Toyama Y, Nakamura M, Okano H: Roles of ES cell-derived gliogenic neural stem/ progenitor cells in functional recovery after spinal cord injury. PLoS One 4: e7706, 2009

25. Lee SH, Heo JS, Han HJ: Effect of hypoxia on 2-deoxyglucose uptake and cell cycle regulatory protein expression of mouse embryonic stem cells: involvement of $\mathrm{Ca} 2+$ / PKC, MAPKs and HIF-1alpha. Cell Physiol Biochem 19: 269-282, 2007

26. Li J, Snyder EY, Sidman RL: Clues to molecular mechanisms by which neural stem cells rescue cerebellar purkinje neurons in nervous mutant mice. (Abt) Internatl Stem Cell Res 3: 33, 2005

27. Liu S, Qu Y, Stewart TJ, Howard MJ, Chakrabortty S, Holekamp TF, McDonald JW: Embryonic stem cells differentiate into oligodendrocytes and myelinate in culture and after spinal cord transplantation. Proc Natl Acad Sci USA 97: 6126-6131, 2000
28. Lu P, Jones LL, Snyder EY, Tuszynski MH: Neural stem cells constitutively secrete neurotrophic factors and promote extensive host axonal growth after spinal cord injury. Exp Neurol 181: 115-129, 2003

29. Matsuda R, Yoshikawa M, Kimura H, Ouji $Y$, Nakase $H$, Nishimura F, Nonaka J, Toriumi H, Yamada S, Nishiofuku M, Moriya K, Ishizaka S, Nakamura $M$, Sakaki T: Cotransplantation of mouse embryonic stem cells and bone marrow stromal cells following spinal cord injury suppresses tumor development. Cell Transplant 18: 39-54, 2009

30. McDonald JW, Liu XZ, Qu Y, Liu S, Mickey SK, Turetsky D, Gottlieb DI, Choi DW : Transplanted embryonic stem cells survive, differentiate and promote recovery in injured rat spinal cord. Nat Med 5: 1410-1412, 1999

31. Mitsui T, Shumsky JS, Lepore AC, Murray M, Fischer I: Transplantation of neuronal and glial restricted precursors into contused spinal cord improves bladder and motor functions, decreases thermal hypersensitivity, and modifies intraspinal circuitry. J Neurosci 25: 9624-9636, 2005

32. Munoz JR, Stoutenger BR, Robinson AP, Spees JL, Prockop DJ: Human stem/progenitor cells from bone marrow promote neurogenesis of endogenous neural stem cells in the hippocampus of mice. Proc Natl Acad Sci USA 102; 1817118176, 2005

33. Nikulina E, Tidwell JL, Dai HN, Bregman BS, Filbin MT: The phosphodiesterase inhibitor rolipram delivered after a spinal cord lesion promotes axonal regeneration and functional recovery.Proc Natl Acad Sci USA 101: 8786-8790, 2004

34. Nistor GI, Totoiu MO, Haque N, Carpenter MK, Keirstead HS: Human embryonic stem cells differentiate into oligodendrocytes in high purity and myelinate after spinal cord transplantation. Glia 49: 385-396, 2005

35. Park KI, Lachyankar M, Nissim S, Snyder EY: Neural stem cells for CNS repair: State of the art and future directions. Review. Adv Exp Med Biol 506: 1291-1296, 2002

36. Park KI, Liu S, Flax JD, Nissim S, Stieg PE, Snyder EY: Transplantation of neural progenitor and stem cells: Developmental insights may suggest new therapies for spinal cord and other CNS dysfunction. J Neurotrauma 16: 675-687, 1999

37. Park KI, Ourednik J, Ourednik V, Taylor RM, Aboody KA, Auguste KI, Lachyankar M, Teng YD, Redmond DE, Snyder EY: Global gene and cell replacement strategies via stem cells. Gene Ther 9: 613-624, 2002

38. Parsons $\mathrm{XH}$, Teng YD, Snyder EY: Important precautions when deriving patient-specific neural elements from pluripotent cells. Cytotherapy 11: 815-824, 2009

39. Pluchino S, Zanotti L, Rossi B, Brambilla E, Ottoboni L, Salani G, Martinello M, Cattalini A, Bergami A, Furlan R, Comi G, Constantin G, Martino G: Neurosphere-derived multipotent precursors promote neuroprotection by an immunomodulatory mechanism. Nature 436: 266-271, 2005

40. Redmond DE Jr, Bjugstad KB, Teng YD, Ourednik V, Ourednik J, Wakeman DR, Parsons XH, Gonzalez R, Blanchard BC, Kim SU, Gu Z, Lipton SA, Markakis EA, Roth RH, Elsworth JD, Sladek JR Jr, Sidman RL, Snyder EY: Behavioral improvement in a primate Parkinson's model is associated with multiple homeostatic effects of human neural stem cells. Proc Natl Acad Sci USA 104: 12175-12180, 2007

41. Reier PJ: Cellular transplantation strategies for spinal cord injury and translational neurobiology. Review. NeuroRx 1:424-451, 2004 
42. Reubinoff BE, Itsykson $\mathrm{P}$, Turetsky $\mathrm{T}$, Pera MF, Reinhartz E, Itzik A, Ben-Hur T: Neural progenitors from human embryonic stem cells. Nat Biotechnol 19: 1134-1140, 2001

43. Rosario CM, Yandava BD, Kosaras B, Zurakowski D, Sidman RL, Snyder EY: Differentiation of engrafted multipotent neural progenitors towards replacement of missing granule neurons in meander tail cerebellum may help determine the locus of mutant gene action. Development 124: 4213-4224, 1997

44. Schaffer DV, Gage FH: Neurogenesis and neuroadaptation. Neuromolecular Med 5: 1-9, 2004

45. Schwab ME: Nogo and axon regeneration. Curr Opin Neurobiol 14:118-124, 2004

46. Sekhon LH, Fehlings MG: Epidemiology, demographics, and pathophysiology of acute spinal cord injury. Review. Spine (Phila Pa 1976) 15: 2-12, 2001

47. Shihabuddin LS, Horner PJ, Ray J, Gage FH: Adult spinal cord stem cells generate neurons after transplantation in the adult dentate gyrus. J Neurosci 20: 8727-8735, 2000

48. Snyder EY, Deitcher DL, Walsh C, Arnold-Aldea S, Hartwieg EA, Cepko CL: Multipotent neural cell lines can engraft and participate in development of mouse cerebellum. Cell 68: 3351,1992

49. Snyder EY, Park KI, Flax JD, Liu S, Rosario CM, Yandava BD, Aurora S: Potential of neural "stem-like" cells for gene therapy and repair of the degenerating central nervous system. Review. Adv Neurol 72: 121-132, 1997

50. Song KJ; Taghavi CE, Lee KB, W JC, Chung KH, Park YG, Nam U: The Effect of human neural stem cells on neural regeneration according to transplantation timing: A rat spinal cord injury model. Neurosurgery Quarterly 19: 228-234, 2009

51. Tator $\mathrm{CH}$ : Review of experimental spinal cord injury with emphasis on the local and systemic circulatory effects. Neurochirurgie 37: 291-302, 1991

52. Teng YD, Choi H, Onario RC, Zhu S, Desilets FC, Lan S, Woodard EJ, Snyder EY, Eichler ME, Friedlander RM: Minocycline inhibits contusion-triggered mitochondrial cytochrome c release and mitigates functional deficits after spinal cord injury. Proc Natl Acad Sci USA 101: 3071-3076, 2004

53. Teng YD, Kabatas S, Li J, Wakeman DR, Snyder EY, Sidman RL: Functional Multipotency of Neural Stem Cells and Its Therapeutic Implications. Ulrich H (ed), Perspectives of Stem Cell. New York, Springer: 2010: 255-271
54. Teng YD, Lavik EB, Qu X, Park KI, Ourednik J, Zurakowski D, Langer R, Snyder EY: Functional recovery following traumatic spinal cord injury mediated by a unique polymer scaffold seeded with neural stem cells. Proc Natl Acad Sci USA 99: 3024-3029; 2002

55. Teng YD, Liao WL, Choi H, Konya D, Sabharwal S, Langer R, Sidman RL, Snyder EY, Frontera WR: Physical activitymediated functional recovery after spinal cord injury: Potential roles of neural stem cells. Review. Regen Med 1: 763776, 2006

56. Teng YD, Mocchetti I, Taveira-DaSilva AM, Gillis RA, Wrathall JR: Basic fibroblast growth factor increases long-term survival of spinal motor neurons and improves respiratory function after experimental spinal cord injury. J Neurosci 19: 7037-7047, 1999

57. Teng YD, Santos F.N., Black PM, Konya D, Park KI, Sidman RL, Snyder EY: Neural stem cells: Multipotency beyond selfrenewal and phenotypic differentiation. Atala A, Lanza R, Thomson JA, Nerem RM (eds), Principles of Regenerative Medicine. San Diego: Elsevier, 2008: 300-317

58. Teng YD, Yu D, Kabatas S, Langer R, Sabharwal S: Neural stem cell mediated multifaceted repair for sci: gdnf perspectives. Poster. Neuroscience Annual Meeting Abstract Book:19, 2007

59. Tewarie RD, Hurtado A, Ritfeld GJ, Rahiem ST, Wendell DF, Barroso MM, Grotenhuis JA, Oudega M: Bone marrow stromal cells elicit tissue sparing after acute but not delayed transplantation into the contused adult rat thoracic spinal cord. J Neurotrauma 26: 2313-2322, 2009

60. Yandava BD, Billinghurst LL, Snyder EY: "Global" cell replacement is feasible via neural stem cell transplantation: evidence from the dysmyelinated shiverer mouse brain. Proc Natl Acad Sci USA 8: 7029-7034, 1999

61. Yu D, Neeley WL, Pritchard CD, Slotkin JR, Woodard EJ, Langer R, Teng YD: Blockade of peroxynitrite-induced neural stem cell death in the acutely injured spinal cord by drugreleasing polymer. Stem Cells 27: 1212-1222, 2009

62. Zhang SC, Wernig M, Duncan ID, Brustle O, Thomson JA: In vitro differentiation of transplantable neural precursors from human embryonic stem cells. Nat Biotechnol 19: 1129-1133, 2001

63. Zietlow R, Lane EL, Dunnett SB, Rosser AE: Human stem cells for CNS repair. Review. Cell Tissue Res 331: 301-322, 2008 